\title{
Rubber plantation labor and labor movements as rubber prices decrease in southern Thailand
}

\author{
Uraiwan Tongkaemkaew ${ }^{1, *}$ and Bénédicte Chambon ${ }^{2}$ \\ ${ }^{1}$ Faculty of Technology and Community Development, Thaksin University, Phatthalung campus, 93120 \\ Thailand \\ ${ }^{2}$ CIRAD, UPR Systèmes de Pérennes, Hevea Research Platform in Partnership (HRPP), Kasetsart University, \\ Bangkok, 10900, Thailand \\ *Corresponding author: t_uraiwan@hotmail.com; Tel.: +66-081-965-5583
}

\begin{abstract}
A decrease in rubber prices can initiate labor migration trends from rubber production to industrial or service sectors, which could further cause labor shortages in rubber production. This case was not studied in the different communities with a long history of rubber such as the center city of southern Thailand. This study analyzes the source of labor and movement of laborers working in rubber plantations in the context of decreasing rubber prices. We selected 3 representative areas, namely rural, suburban and urban communities in Hat Yai district, Songkhla province. Owners of rubber holdings were the target group for the survey, and individual interviews were conducted. We collected data between March and July 2015, engaging with 207 owners. The results showed that family labor and hired labor were widely used in rubber plantations in the three communities. Locally hired laborers and laborers from other countries were the main sources of hired labor for rubber plantations. The transnational laborers were a secondary source of labor for all communities, especially the rural ones. Family labor was the main source of labor for smallholder rubber plots, especially for the urban and suburban areas. Hired labor was used in all sizes of rubber holding in rural and suburban communities and were very common in the small rubber holdings in urban areas. This shows that the rubber production sector creates employment for local people and for migrants. Furthermore, low rubber price conditions did not significantly impact labor movement in rubber plantations. However, rubber plantations in urban and suburban communities lacked labor supply due to their proximity to the larger urban center of Hat Yai city. Therefore, the low tapping intensity and generate the diversified source of income to attract young labor generation to work on the farms should be policy to maintain natural rubber production in Thailand.
\end{abstract}

Keywords: labor migration; labor productivity; rubber farming; rural; suburban; urban

\section{Introduction}

With $3,734,452$ hectares (ha) planted area in Thailand, rubber is the main cash crop in the southern Thailand regions with 2,332,685 hectares. This region is historically the largest rubber growing area with around $62.46 \%$ of the total area under rubber plantations (OAE, 2016). Rubber prices have been continuously decreasing since 2012: from 2012 to 2015, the annual average farm gate prices dropped every year from $87.15,74.75$ and 53.93 to 44.17 baht per kg (latex prices) (OAE, 2016a). Low rubber prices impact household income among smallholders highly dependent on rubber income. This has led to difficulties in generating income for rubber smallholdings and has also raised household debts. The data from the National Statistic Office (NSO) showed that the households debt in Southern Thailand has increased during 2011, 2013 and 2015 from 110,723, 139,931 to 163,892 baht per household, respectively (NSO, 2015). However, this data did not explain the cause of debt. The Bank of Thailand data also showed the proportion of debt among households by occupation in this part of the country, which reflect conditions as follows: own business on-farm $35 \%$; own business off-farm $27 \%$; managers/academic staff/government staff/ $19 \%$; hired labor $12 \%$; and other category at $7 \%$.

For the own business on-farm category, the data pointed out that rubber prices were closely related to the debts and predictions by 2018 , and that household debt are projected to increase 
(Wanasuk et al., 2014). In this situation, diversifying the sources of income is a way to improve rubber holders. However, global dynamic contents could create constraints or opportunities for households to generate diversified income. The urban and transition communities, which are normally nearby cities and industrial zones, may easily provide sources of off-farm income. Chevapat (1994) also showed that rubber labor in plantations near factories migrated to industrial factories because they could adjust themselves to working both in the rubber plantation and in the factory. However, younger generations are more and more reluctant to work in rubber plantations (Kongmanee, 2015). Thongpan (2014) also highlights that rubber plantations encouraged family members who migrated out to return home. Factors encouraging family labor to return home include social conditions, such as: the responsibility of caring for elders, a sense of freedom from being controlled by employers and corresponding ability to control their own labor; economic conditions; income security; and, reduction of cost of living; and, overall labor conditions. This migration reflects the flexibility of labor use in farm households and also indicates trends in reagrarianization.

Nevertheless, research has not analyzed the particular impact of labor movement on rubberbased households income, particularly in the context of declining prices, and the fact that it consists of such a major part of the economy in the Southern Thai region. This could further indicate the potential for new trends in labor priorities and labor movements. Therefore, the hypothesis to be tested in this paper concerns the extent to which the decline of rubber prices affects labor movement differently depending on the communities characterized by their proximity to other labor opportunities, such as in cities. We therefore analyzed the use of labor in rubber plantations and labor mobility in the contexts of rural, semi-urban and urban communities.

\section{Materials and Methods}

We selected Songkhla province as our main study site because it is representative of the southern rubber producing areas. Rubber has been historically grown here and it is now the second largest province in terms of planted area. For data collection, we focused on Hat Yai district due to the potential to analyze three sample classes of communities that could be characterized as urban, suburban and rural, considering the population density and distance. We defined urban area based on the population density, and rural area on the level of agricultural activity. The mapping of three communities also took into consideration the distance from the city $(5-10 \mathrm{~km}$ of urban, $10-15 \mathrm{~km}$ of semi-urban and more than $15 \mathrm{~km}$ of rural). Finally, we selected Kuan Lang subdistrict as the site most representative of the urban community; followed by Baan Pru sub-district as representing the middle range or suburban area; and, Pa Tong sub-district as the outermost area, which contains representative features of the rural area. Upon site selection we conducted interviews and organized discussions with key informants to select the communities for study, including: representative staff of the Rubber Authority of Thailand (RAOT) in Songkhla province; staffs from the Sub-district Administration Organization or Municipal Administration. We also incorporated secondary data of rubber planted areas and rubber households that we were able to access. Thereafter, we conducted surveys with the village leaders using interview guides. Finally, we selected 3 villages to represent each community (Figure 1).

Data were collected through individual interviews with rubber owners. We used a semistructured questionnaire with different categories of questions to identify the labor used on the farm and the labor migration patterns in the period 1956 to 2015 in the three communities. We selected the rubber owners by purposive sampling using the following criteria: own labor used in rubber plantations; employed labor; rubber holding size; source of hired labor; the year of labor migration; and, the number of persons who moved in and out of rubber plantations. Then, we conducted individual interviews with 207 farmers: 82 households from the rural community, 76 from suburban, and 49 from urban. Field work was conducted between March and July 2015 (we 
spent 6 days in each village).

Hat Yai district, Songkhla province, Thailand

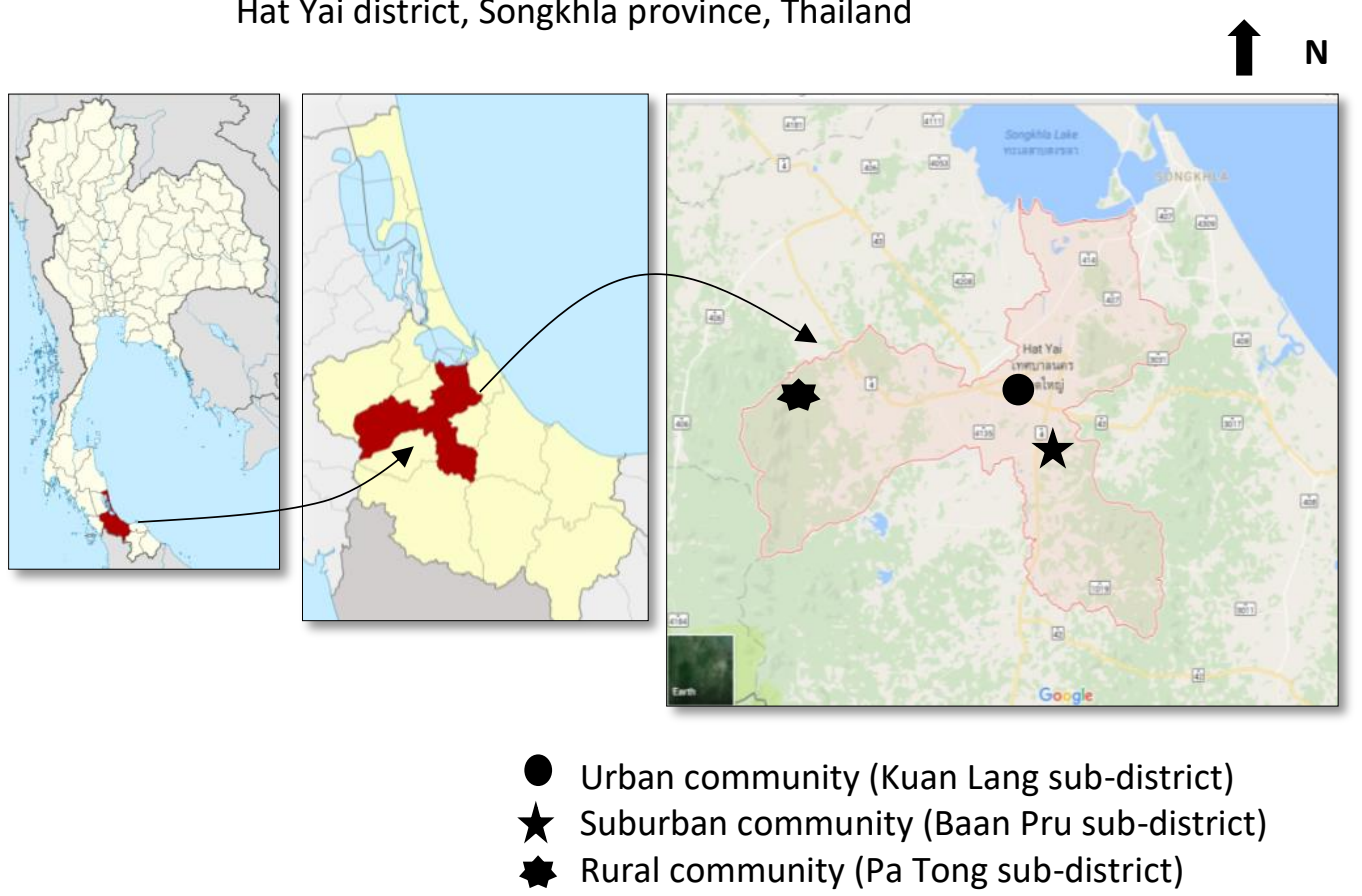

Figure 1 Site study

\section{Results and Discussion}

\subsection{Labor in rubber groves}

The labor used in rubber plantations in the three communities were divided into three categories: family labor only (FLO), hired labor only (HLO) and a combination of both family and hired labor (BL). Considering the three communities together, the most common category of labor used was family labor only ( 101 hhs or $48.79 \%$ of the total sample) followed by hired labor only ( 74 hhs or $35.75 \%$ of the total sample) and the both family and hired labor ( 32 hhs or $15.46 \%$ of the total sample) (Table 1).

Looking at the distribution of the three categories of labor for each community, differences arise. In suburban and urban communities, the most common category of labor was family labor only $(44.74 \%$ and $69 \%)$, while it was hired labor only in rural areas (46.34\%). The percentage of farms using both families and hired labor in rubber plantations was the smallest for rural and suburban communities (but not for the urban community for which hired labor only is the smallest). In sum, rubber plantations in rural and suburban households have a high demand for hired labor to work in rubber plantations $(59.75 \%$ and $55.26 \%$, respectively) but in urban communities, households have the lowest demand for hired labor (30.62\%) (Table 1).

Table 1 Labor used in rubber plantations for the three communities.

\begin{tabular}{lcccccccc}
\hline \multirow{2}{*}{$\begin{array}{l}\text { Labor used in rubber } \\
\text { plantation }\end{array}$} & \multicolumn{2}{c}{$\begin{array}{c}\text { Rural } \\
(\mathrm{n}=82)\end{array}$} & \multicolumn{2}{c}{$\begin{array}{c}\text { Suburban } \\
(\mathrm{n}=76)\end{array}$} & \multicolumn{2}{c}{$\begin{array}{c}\text { Urban } \\
(\mathrm{n}=49)\end{array}$} & \multicolumn{2}{c}{$\begin{array}{c}\text { Total } \\
(\mathrm{N}=207)\end{array}$} \\
\cline { 2 - 10 } & No. $\mathrm{hh}$ & $\%$ & No. hh & $\%$ & No. hh & $\%$ & No. hh & $\%$ \\
\hline 1) FLO $(\mathrm{n}=101)$ & 33 & 40.24 & 34 & 44.74 & 34 & 69.39 & 101 & 48.79 \\
2) HLO $(\mathrm{n}=74)$ & 38 & 46.34 & 30 & 39.47 & 6 & 12.24 & 74 & 35.75 \\
3) BL $(\mathrm{n}=32)$ & 11 & 13.41 & 12 & 15.79 & 9 & 18.37 & 32 & 15.46 \\
\hline Total & 82 & 100.00 & 76 & 100.00 & 49 & 100.00 & 207 & 100.00 \\
\hline
\end{tabular}


Note: FLO=Family labor only, $\mathrm{HLO}=$ Hired labor only, $\mathrm{BO}=$ Both labor

Considering the three communities together, the farms with small rubber area $(<3.2 \mathrm{ha})$ mainly used family labor only $(40.09 \%)$ unlike farms with larger rubber area (>3.2 ha) $(8.69 \%)$. Using hired labor only was less common but dominates in the large rubber area (>3.2 ha) $(16.9 \%)$ and it is also important in the farms with very small rubber plantations ( $<1.6$ ha) $(11.59 \%)$. This shows that for those who own a small rubber area ( $<3.2 \mathrm{ha})$ in an urban community, family labor was important $(60.3 \%)$ and those who own a large rubber area ( $>3.2 \mathrm{ha}$ ) in a rural community, hired labor only was important (20.73\%). Both family and hired labor were used in various rubber holdings in rural and suburban communities (Table 2). Considering the whole sample, local people and foreign migrants were the most important sources of hired labor in rubber production in the three communities (46.67\%). Local labor was highly used in the suburban community $(61.90 \%)$ and urban community $(57.14 \%)$. Foreign laborers were in high use in the rural community $(63.27 \%)$ and urban community (42.86\%) and to a lesser extent in suburban communities (28.54\%). It is in the suburban community that the percentage of households employing labor coming from other provinces was the highest; but this category of labor was completely absent in urban areas (Table 3).

Table 2 Labor used in the different rubber holding sizes in three communities.

\begin{tabular}{lllllllll}
\hline $\begin{array}{l}\text { Source of hired labor } \\
\text { in rubber plantation }\end{array}$ & $\begin{array}{l}\text { Rural } \\
(\mathrm{n}=82)\end{array}$ & \multicolumn{3}{c}{$\begin{array}{l}\text { Suburban } \\
(\mathrm{n}=76)\end{array}$} & $\begin{array}{l}\text { Urban } \\
(\mathrm{n}=49)\end{array}$ & & $\begin{array}{l}\text { Total } \\
(\mathrm{N}=207)\end{array}$ \\
\cline { 2 - 9 } & No. hh & $\%$ & No. hh & $\%$ & No. hh & $\%$ & No. hh & $\%$ \\
\hline $\begin{array}{l}<1.60 \text { ha }(\mathrm{n}=91) \\
\text { 1) FLO }\end{array}$ & 12 & 14.63 & 20 & 26.32 & 27 & 55.10 & 59 & 28.50 \\
2) HLO & 11 & 13.41 & 9 & 11.84 & 4 & 8.16 & 24 & 11.59 \\
3) BL & 0 & 0.00 & 2 & 2.63 & 6 & 12.24 & 8 & 3.86 \\
1.61-3.2 ha (n=49) & & & & & & & 0 & \\
1) FLO & 11 & 13.41 & 8 & 10.53 & 5 & 10.20 & 24 & 11.59 \\
2) HLO & 10 & 12.20 & 5 & 6.58 & 0 & 0.00 & 15 & 7.25 \\
3) BL & 3 & 3.66 & 5 & 6.58 & 2 & 4.08 & 10 & 4.83 \\
3.21-4.8 ha (n=37) & & & & & & & 0 & \\
1) FLO & 6 & 7.32 & 4 & 5.26 & 1 & 2.04 & 11 & 5.31 \\
2) HLO & 8 & 9.76 & 12 & 15.79 & 1 & 2.04 & 21 & 10.14 \\
3) BL & 2 & 2.44 & 2 & 2.63 & 1 & 2.04 & 5 & 2.42 \\
> 4.8 ha (n=30) & & & & & & & 0 & \\
1) FLO & 4 & 4.88 & 2 & 2.63 & 1 & 2.04 & 7 & 3.38 \\
2) HLO & 9 & 10.98 & 4 & 5.26 & 1 & 2.04 & 14 & 6.76 \\
3) BL & 6 & 7.32 & 3 & 3.95 & 0 & 0.00 & 9 & 4.35 \\
\hline Total & 82 & 100.00 & 76 & 100.00 & 49 & 100.00 & 207 & 100.00 \\
\hline
\end{tabular}

Note: FLO=Family labor only, $\mathrm{HLO}=$ Hired labor only, BO=Both labor.

Table 3 Source of hired labor in rubber plantations for the three communities.

\begin{tabular}{lllllllll}
\hline Source of hired labor & Rural & \multicolumn{3}{c}{ Suburban } & Urban & \multicolumn{3}{c}{ Total } \\
\cline { 2 - 9 } in rubber plantation & No.hh & $\%$ & No.hh & $\%$ & No.hh & $\%$ & No.hh & $\%$ \\
\hline Local & 15 & 30.61 & 26 & 61.90 & 8 & 57.14 & 49 & 46.67 \\
Other provinces & 3 & 6.12 & 4 & 9.52 & 0 & 0.00 & 7 & 6.67 \\
Other countries & 31 & 63.27 & 12 & 28.57 & 6 & 42.86 & 49 & 46.67 \\
\hline Total & 49 & 100.00 & 42 & 100.00 & 14 & 100.00 & 105 & 100.00 \\
\hline
\end{tabular}


Our results show that the foreign laborers were employed instead of local labor in rural and urban communities show a lack of indigenous labor in rubber plantations. Due to the young generation in the family in the rural community are currently asses in the higher levels of education and some people are work in the urban areas while labors in the urban and suburban communities are informal moving to service and industrial sectors. Also, the agriculture sector is not popular interesting for the new generation. This could have adverse impacts on rubber households since foreign laborers cannot receive training from the RAOT. They are therefore generally less skilled than local laborers who can benefit from formal training. Tansri (n.d.) identified three main causes of a labor shortage in the agriculture sector in Thailand:

1) The attitude of the new generations of workers who consider that agriculture is drudgery work. Furthermore, the price uncertainties create risky income conditions and furthermore, production depends on natural conditions. This encourages workers moving to non-agricultural sectors to operate more as an employee of the establishment.

2) The cost of production of major crops is increasing, especially the cost of chemical fertilizers and agrochemicals as well as the increasing costs of wage labor. As a result, the net return is declining.

3) The insurance of agricultural crops is still limited and not widely known due to lack of promotion and support among governing institutions. Farmers face the risk of natural disasters, which can have serious negative consequences on output.

In addition, Benjamin (1992) shows that family labor on-farm demand is independent of the family composition, family strategy and choice in terms of activities. For example, in a large family, members that initially present labor opportunity can choose to work off-farm. Somboonsuk et al. (2011) found such conditions regarding agricultural labor migration in Southern Thailand, in which labor in rural and suburban areas had increasing trends of migrating to urban areas. Moreover, for the current labor situation of Thailand, young people in the agricultural sector have moved out of agriculture to other industries in search of better income conditions. The factors that affect such desires include the average income in agriculture per year is lower, changing demographics, increasing education levels, larger household sizes in relation to lower average farm sizes per capita, and an increasing number of farmers with large debts. In addition, non-farm income appears more stable, which has incentivized agricultural workers to move outside of the agricultural sector. In particular, the majority of the children of farmers are graduating with higher levels of education and gradually entering a more industrialized phase of development (OAE, 2016b). These broader factors account for the causes of using hired labor in rubber production in the three communities, which are trends that are expected to continue in the future. However, the reasons for rubber owners to employ hired labor especially from other countries, as well as the limited availability of family labor require further investigation.

\subsection{Rubber prices affecting labor migration}

The results of the survey showed that labor in relation to rubber plantations have been migrating for the past 59 years, in this case from 1956 to 2015. The data showed that some family labor moved in and out of the rubber production sector more than once in the past 59 years. Hired laborers did not move out from rubber sector, but they changed owners in urban, suburban and rural communities. In considering the three communities examined in this study together, for both family and hired labor, the migration out of the rubber sector (around 55\%) was higher than the migration into the rubber sector (around 45\%). However, family labor had higher in-migration to a rubber plantation in a rural community while in suburban - and particularly in urban communities - out-migration of family labor from rubber plantations was more abundant than out-migration. But for hired labor, migration out of the rubber sector was always higher than in-migration and it was particularly high in rural communities. (Table 4). 
Table 4 Movement of laborers in a rubber plantation in the three communities.

\begin{tabular}{|c|c|c|c|c|c|c|}
\hline \multirow[t]{2}{*}{ Labor/community } & \multicolumn{6}{|c|}{$\begin{array}{l}\text { Number of laborers migration in rubber plantations (person) from } \\
1956 \text { to 2015* }\end{array}$} \\
\hline & moved in & $\%$ & moved out & $\%$ & Total & $\%$ \\
\hline \multicolumn{7}{|l|}{ Family labor } \\
\hline Rural & 104 & 53.06 & 92 & 46.94 & 196 & 38.43 \\
\hline Suburban & 85 & 45.21 & 103 & 54.79 & 188 & 36.86 \\
\hline Urban & 41 & 32.54 & 85 & 67.46 & 126 & 24.71 \\
\hline Total & 230 & 45.10 & 280 & 54.90 & 510 & 100.00 \\
\hline \multicolumn{7}{|l|}{ Hired labor } \\
\hline Rural & 18 & 38.30 & 29 & 61.70 & 47 & 12.30 \\
\hline Suburban & 72 & 49.32 & 74 & 50.68 & 146 & 38.22 \\
\hline Urban & 83 & 43.92 & 106 & 56.08 & 189 & 49.48 \\
\hline Total & 173 & 45.29 & 209 & 54.71 & 382 & 100.00 \\
\hline
\end{tabular}

Note: * one laborer could have moved out and in more than one time.

The labor movements in rubber plantations fluctuated over time. There were several peaks for family labor to move into rubber production in 1977, 1985, 1992, 1995 and 2005. There was also a peak in rural communities in 1995 and 2005. During those periods, family labor moving out was less common. There was also a peak for moving out in 1985 in rural and suburban communities and one in 1995 in the urban community (Figure 2: A1 and A2). For hired labor there were small and fluctuating moves especially between 1975 and 1992 and later in 2005 and between 2010 and 2013. Finally, there were also limited fluctuations of moving out especially in urban communities beginning in 1996 (Figure 2: B1 and B2). This points to the fact that rubber plantations in rural communities attracted family labor. On the other hand, more hired labor quit the rubber production sector in rural communities than in suburban and urban communities.

In our analysis of rubber price fluctuations and labor migration, we found that there is no clear impact of rubber prices on the labor movement. Family labor moving into the rubber sector did not follow the rubber price increase. This is in contrast with previous studies conducted in Africa (Ruf, 2001; Chambon \& Gobina Mokoko, 2013) showing that the increase in cash crop prices encouraged family labor to come back and work in the plantations. This study showed conditions of hired labor in-migration to rubber plantations, while family labors pursued livelihood opportunities through out-migration during the same period (Figure 3: A1 and B1). However, family labor also tended to move out from rubber plantations in certain periods, especially during 2014 to 2015, when the rubber price dropped around 53.93 to 44.17 baht $/ \mathrm{kg}$ (Figure 3 A2). Meanwhile, high rubber prices in 2011 (124 baht/kg) found increased labor employment in an urban community (Figure 3: B2). Weaving (1994) noted that, when rubber prices fall, smallholders and share tappers have tried to increase yield to maintain their income. More frequent tapping has reduced the productive life of the trees however, and more significantly, reduced the tapping labor productivity leading to a severe labor shortage. However, this study did not analyze the impact of rubber price decreases on the movement of labor in the rubber production sector. Nevertheless, our results about labor migration in and out of rubber sector indicate that labor in the rubber production sector tended to decrease (Table 4 and Figure 2). 
Number of family laborer moved in to rubber plantations (person)

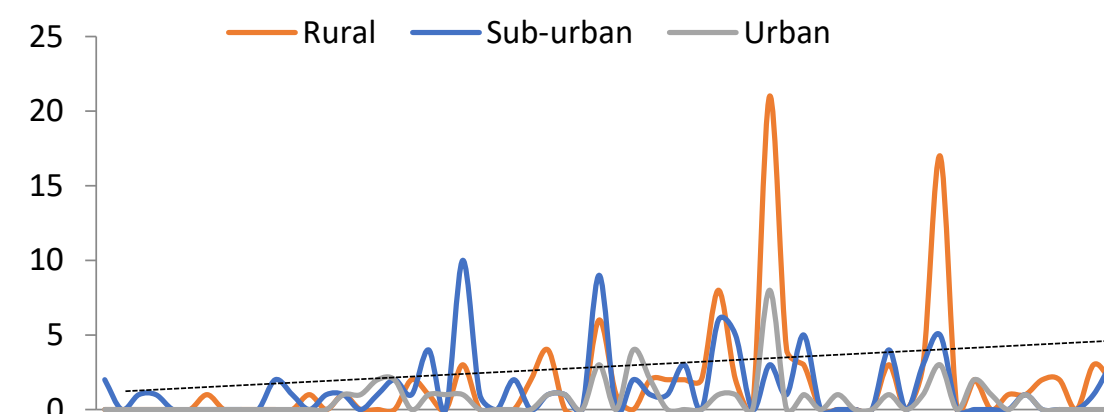

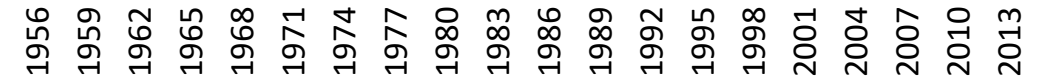

Number of family laborer moved out from rubber plantations (person)

(A2)

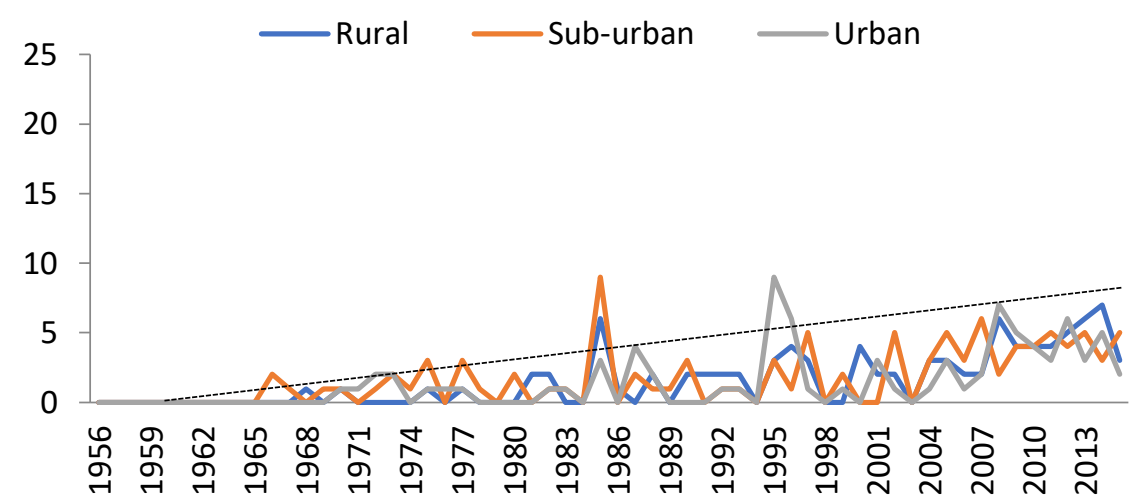

(A1)

0

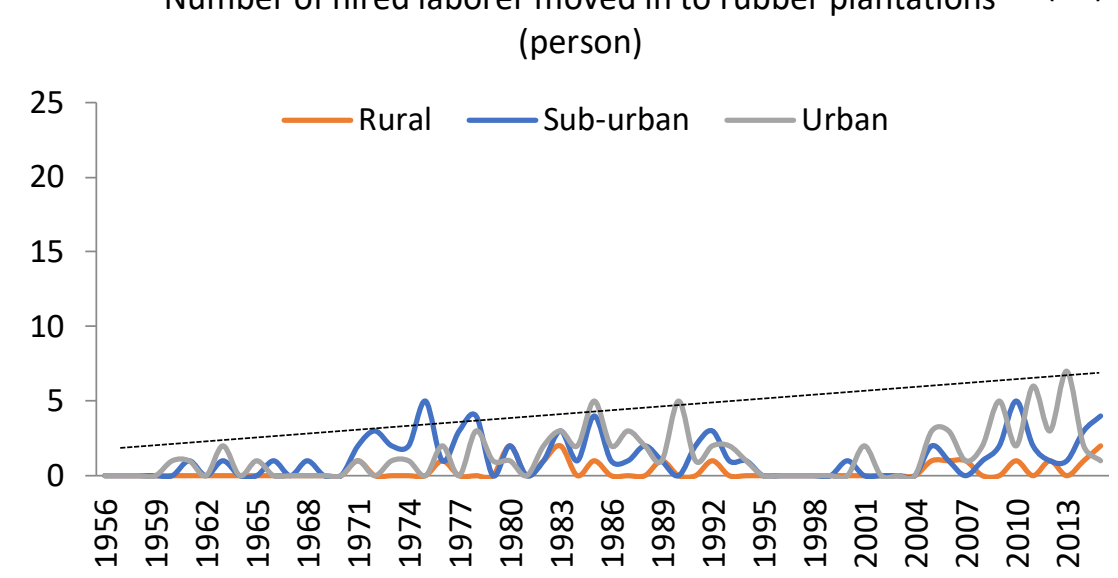

Number of hired laborer moved in to rubber plantations (person)

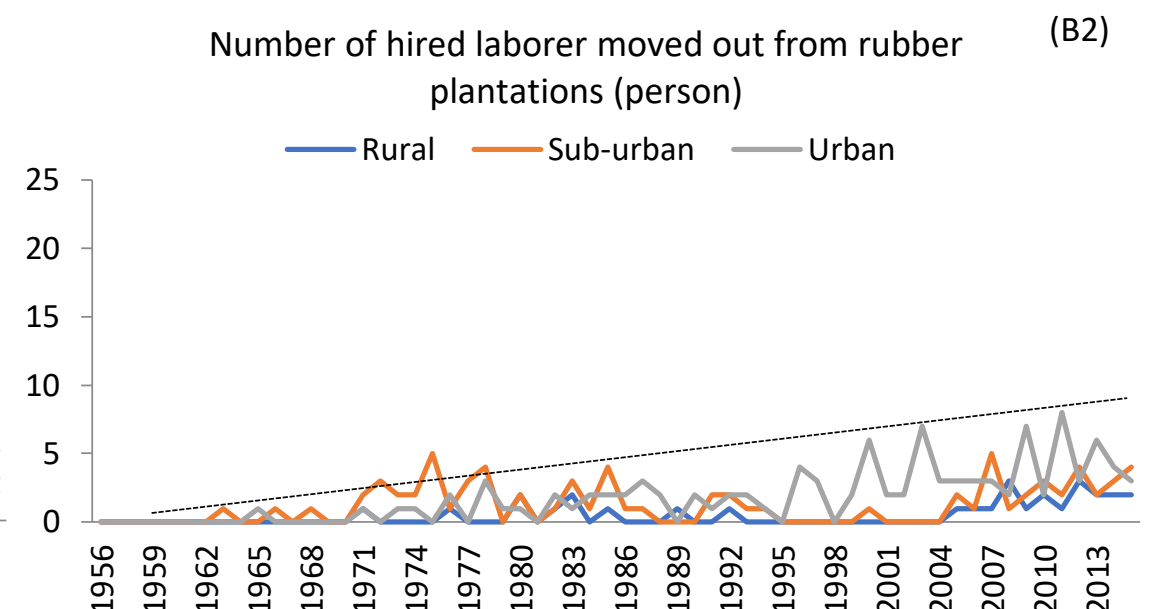

Figure 2 The time period of laborer movement in and out of rubber plantations in three comm
out (A2) and hired labor moved in (B1) and moved out (B2) from rubber plantations.

Note: one laborer could move out and in more than once. 

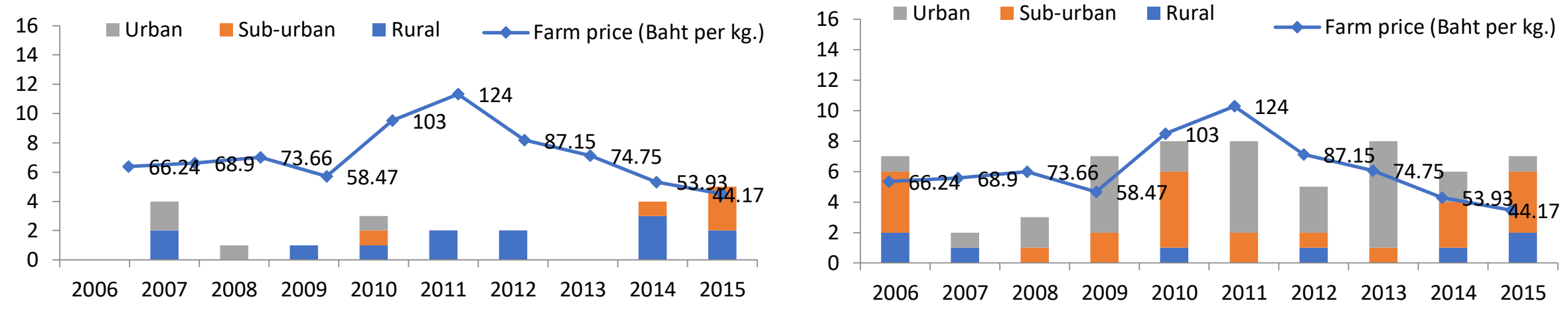

Number of family laborer move $d$ out from rubber plantation (person)

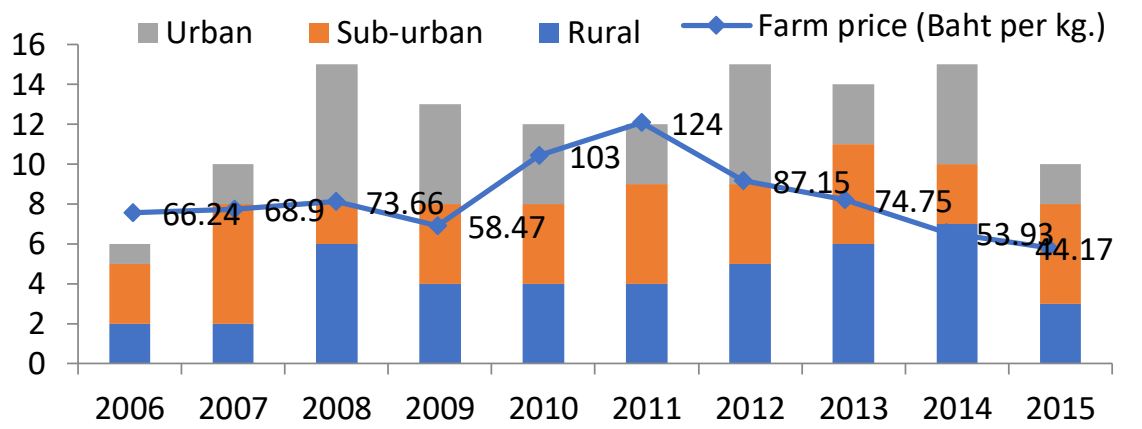

(A2)

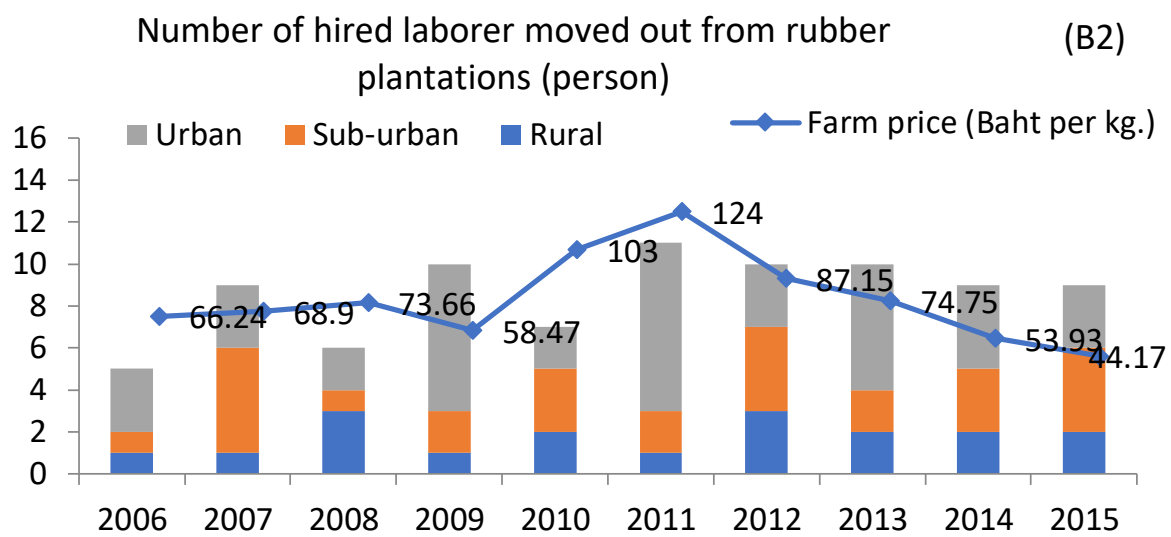

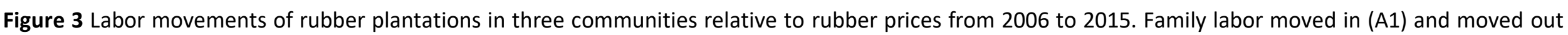
(A2) and hired labor moved in (B1) and moved out (B2) in rubber plantations. Noted: one laborer could be moved out and in more than one time. 
The suburban communities in an industrial zone, and the urban communities in service sector zones, attract labor moving out from the rubber sector. Although the rural area was far away, the out-migration was also found there because it was convenient to enter the industrial zone. Domestic labor in rubber production sector was lacking particularly in urban and suburban communities. Nobnorb \& Fongsuwan (2014) mentioned that domestic labor has more and more difficulty to provide sufficient labor due to the increases in both cultivation and production of rubber. Consequently, migrant workers are often necessary to meet the shortfalls within the Thai rubber sector. As such, the lack of skilled labor results in higher production costs and creates a competitive disadvantage in the global arena. Furthermore, Weaving (1994) also noted that in the long run, income from rubber tapping can only be maintained by reducing the number of workers and introducing new technologies to make tapping more productive by reduced tapping frequency with ethylene stimulation. Rationalized tapping practices can increase labor productivity and farmer profit margins. It is recommended that the number of tapping days is substantially reduced while introducing a chemical stimulant to maintain yield per unit area close to their present levels. This advice will be a solution to the labor shortage in future rubber planters.

\section{Conclusion}

The analysis of labor used in rubber plantations and labor mobility in the rural, suburban and urban communities showed that family labor and hired labor were important factors in rubber production. The family labors were significantly used in the small rubber size in three communities. Rubber plantation owners in rural communities mostly used hired labor whereas rubber plantation owners in suburban, and particularly urban, communities used family labor only. The hired labor from other countries was also a major source of labor for the rubber production sector, particularly in rural areas. There was no clear expected impact that emerged from the low rubber price situation on the labor movement, and rather, domestic labor began to move out, and labor from other countries began to move in. Therefore, there was a shortage of domestic labor in the three communities but foreign migrant laborers were available to compensate for the shortages. The ROAT should be attention to increase labor productivity by providing training in the new tapping systems with low tapping intensity and the DOAE (Department of Agricultural Extension) should be generate diversified sources of income to attract young generation of laborers to work on rubber farms.

\section{References}

Benjamin, D. (1992). Household composition labor markets and labor demand: testing for separation in agricultural household models. Econometrica, 60 (2): 287-322.

Chambon, B. \& S. Gobina Mokoko. (2013). Determinants of the choice of tree crops in diversified farming systems of the rubber smallholders in wouth-west Cameroon. In Tropical Tree Crops. (Ed.) Economical and ecological challenges of diversification. Vrsailles, Quae.

Chevapat, N. (1994). An economic analysis of factors of production in rubber Industry and labour migration: A case study of Trang province. Bangkok, Thailand: Chulalongkorn University. [in Thai]

Kongmanee, C. (2015). Path dependence of agrarian change: an institutional economic analysis of the rubber economy in Southern Thailand. PhD diss., Montpellier SupAgro.

Nobnorb, P \& W. Fongsuwan. (2014). Factors affecting free labor movement amongst rubber industry workers within the ASEAN economic community-AEC. Research Journal of Business Management, 8(4): 427-439.

NSO (National Statistical Office). (2015). The average of debt per household by region and province of 1998-2015. Retrieved from service.nso.go.th/nso/web/ statseries/tables/00000_Whole_Kingdom/Table3.xls. [in Thai]

OAE (Office of Agricultural Economics). (2016a). Agricultural Statistics of Thailand 2015. Office of Agricultural Economics, Ministry of Agriculture and Cooperatives, Thailand. [in Thai] 
OAE. (2016b). The trend of Thai elder workers in agriculture sector, suggestion to improve labor skill- welfare -technology. News 22/2016, 12 February 2016. Retrieved from http://www.oae.go.th/ewtadmin/ewt/oae_web/ewt_news.php?nid=21823\&filename=inde x_green. [in Thai]

Ruf, F. (1995). From the forest rent to the tree capital; basic laws of cocoa cycles. In Ruf, F. and Siswoputanto, P.S. (Eds.) Cocoa Cycles. The economics of cocoa supply (pp. 1-53). Cambridge: Wood head publishing.

Somboonsuk, B., P. Wettayaprasit, K. Pacheera \& P. Kroeksakul. (2011). Comparison of career change and resource management of rubber smallholders. Kasetsart Journal (Social Sciences) 32: $29-40$.

Tansri, K. (n.d.). Labour Changes in Agriculture Sector of Thailand, Bank of Thailand. Retrieved from https://www.bot.or.th/Thai/.../DocLib.../04-Labor\%20with\% 20Agri\%20Changing.pdf. [in Thai]

Thongpan, S. (2014). The incoming of rubber plantation and decision to return home: case study of farm households in Huay Kong basin. Journal of Sociology and Anthropolog, 33(2): 73-102.

Wanasuk, K. J. Kosako \& P. Chuawanla. (2014). Household debts in southern Thailand, bank of Thailand. Retrieved from www.bot.or.th/Thai/ MonetaryPolicy/Southern/DocLib/การศึกษาเชิงลึกเรื่อง\%20หนี้ครัวเรือนกับเศรษฐกิจภาคใต้. pdf. [in Thai]

Weaving, R. (1994). Revitalizing Tree Crops: Rubber in Thailand. Retrieved from http://documents.worldbank.org/curated/en/410861468132603631/pdf/28493.pdf 